\title{
The Significance of the Ancient Near Eastern Treaty Pattern
}

\author{
By J. A. Thompson
}

The ATTEMPT тo identify and isolate smaller blocks of literature, to classify them according to their type or category (Gattung), and to define the original 'situation in life' (Sitz im Leben) in which they arose has provided a useful line of study in both the Old and the New Testaments. The method has been particularly fruitful in studies in the Psalter, ${ }^{1}$ but it has found application in all areas of the Old Testament. One of the results of progress in this study has been that the Introductions to the Old Testament of recent years have included an Introductory chapter on the literary forms that occur in the Old Testament. ${ }^{2}$

While the method of Form-Criticism may be open to the danger of subjectivism, it is undoubtedly of very great value, and when used with a proper consideration of all the factors which go to produce a piece of literature-historical, religious, cultural, literary, etc., it is capable of producing significant results. An understanding of the Sitz im Leben of a particular type of literature is fundamental to a true appreciation of its nature, and is basic for accurate exegesis.

The recognition by G. E. Mendenhall in $1954^{3}$ that the treaty pattern of the ancient Near East could be recognized in many areas in the Old Testament was a significant discovery. The nature of that pattern and the comparative fixety of its form among the Hittites had been recognized earlier by V.Korošec, ${ }^{4}$ who, although he distinguished between parityand suzerainty treaties, was able to show that the literary formulation of both kinds of treaty followed much

I. S. Mowinckel, The Psalms in Israel's Worship, I951, ET, 1962.

A. Weiser, The Psalms, 5th. Ed. Revised, 1959, ET, 1962.

2. A. Bentzen, Introduction to the Old Testament, 1959.

O. Eissfeldt, Einleitung in das Alte Testament, 1956.

A. Weiser, Introduction to the Old Testament, ET, 196r.

3. G. E. Mendenhall, 'Law and Covenant in Israel and the Ancient Near East', B.A., XVII, I 954, pp. 26-46, 49-76.

4. V. Korošec, Hethitische Staatsverträge, 1931 . 
the same lines. The standard elements in these treaties were (i) the preamble, which gave the names and titles of the parties involved, (ii) the historical prologue which outlined the events that led up to the treaty, (iii) the stipulations, which were of two kinds-the general principles on which future relations were to be built, and the specific stipulations which arose out of these general principles, (iv) the divine witnesses and guarantors of the treaty, (v) the associated maledictions and benedictions. Other elements appear in many of the treaties such as the requirement to deposit the treaty in the temple, to read it periodically in a public assembly, and to secure the continuity of the treaty by a suitable succession on the vassal's throne. There is also a good deal of evidence that a religious ceremony accompanied the ratification of a treaty. Quite commonly blood sacrifices were offered on such an occasion. ${ }^{5}$ The formal oath of acceptance and the preparation, sealing, handing over and acceptance of the treaty document were also essential elements in the total proceedings.

In the Old Testament parity treaties may be recognized in Genesis 2 I (Abraham and Abimelech), Genesis 26. (Isaac and Abimelech), Genesis 3I (Laban and Jacob) and perhaps I Kings 5 (Solomon and Hiram). In view of the widespread occurrence of this type of treaty in the Near East in the second millennium B.C. there is no reason to deny the authenticity of these Old Testament narratives.

Of more immediate interest, however, are the suzerainty treaties. There is enough extant material in published form today ${ }^{6}$ to make it possible to claim that although there was a well known pattern in use in the Near East in the second millennium, the constancy of pattern did not lead to a uniformity of detail. The standard literary pattern was adapted to particular occasions, and inside a broadly standard form there could be considerable variation both in the order in which the various elements appeared, and in the content of the sections. At times one or other of the elements is lacking. But the pattern is constant enough to enable a reconstruction of broken documents with some degree of certainty. ${ }^{7}$

5. D. J. Wiseman, The Vassal Treaties of Esarhaddon, 1958, p. 28.

6. E. F. Weidner, Politische Dokumente aus Kleinasien, published in Boghazkoi Studien, 8 and 9 .

J. Friedrich, Staatsverträge des Hatti-Reiches, published in MVAG, $3 \mathrm{I}$ and 34 .

J. Nougayrol, Le Palais Royal d'Ugarit, 1956.

7. D. J. Wiseman, op. cit., pp. Iff.; J. Nougayrol, op. cit., pp. 84f. 
In second millennium treaties the historical introduction was of considerable importance. ${ }^{8}$ In this the great king recounted the many benevolent acts he had performed in the past on behalf of his vassal. These provided sufficient reason for the submission of the vassal to one who had granted such favours to an unworthy recipient, so that he promised obedience in the future as his grateful response to the benefactor for the benefits (real or imaginary) that he had received in the past.

It is precisely the literary form of the suzerain-vassal treaty particularly that of the Hittites of the second millennium B.C., that is used in the Old Testament to describe the covenant between Yahweh and Israel. Such passages as Exodus I9-24, Joshua 24, and Deuteronomy as a whole or in some of its parts, as well as a considerable variety of other passages in the Old Testament may be interpreted readily in terms of the standard Near Eastern treaty. The literary form, and to some extent the language, was used to describe both the original Sinai covenant, and various renewals of that covenant. In many passages, aspects of the total pattern may be clearly discerned also.

The significance of the Near Eastern treaty pattern for Old Testament study may be illustrated by reference to four areas in which it has proved a useful tool for research.

(a) The literary analysis of particular passages.

As an example of a typical covenant Gattung we may consider Genesis 3 I which records the establishment of a covenant between Jacob and Laban. It is not difficult to see in verses 14-43 the historical background to the covenant. In verse 44 the expression 'And now' appears quite in the manner of its appearance in other passages where the call to make a covenant appears after a historical review. ${ }^{9}$ According to the older documentary analysis verses I 4-43 were attributed to $\mathrm{E}$ while verses $44-54$ are divided between $\mathrm{J}$ and $\mathrm{E}$. One way of dividing the verses is- $\mathrm{J}$ : verses $46,48,49,50$ and E: verses 44, 45, 47, 5I-54. According to $G$. von $\operatorname{Rad}^{10}$ 'one can still sense...the rather abrupt and unmotivated transition from verse 43 to verse $44^{\prime}$. We may suggest that a certain abruptness is to be expected when the narrator leaves the historical background to

8. V. Korošec, op. cit., pp. I2ff., 3 Iff.; G. E. Mendenhall, op. cit., pp. 32f.; W. L. Moran, Biblica, 41, i 960 , pp. $297 \mathrm{ff}$.

9. Exod. 19: 5, Josh. 24: 14, I Sam. I2: 13 etc.

ı. G. von Rad, Genesis, ET, I961, p. 306. 
speak of the covenant appeal, 'Now then, in the light of all this let us make a covenant'.

If we summarize what is thought to be the $J$ account we learn that Jacob erected a heap of stones which Laban accepted as a 'witness'. An oath was taken invoking Yahweh to 'keep watch' between them (verse 49), that is, to act as guarantor of the covenant, or 'witness' (verse 50). The terms of the covenant are given in verse 50 and there is a reference to a ritual meal in verse 46 . On the other hand, the E account records the invitation of Laban to make a covenant (verse 44), the setting up of a pillar by Jacob (verse 45), the declaration by Laban that he would honour the agreement and that he expected Jacob to do the same (verse 52), the oath sworn by both Laban and Jacob (verse 53) and the offering of a sacrifice and the eating of a ritual meal by Jacob (verse 54 ).

In order to obtain the complete picture of a typical Near Eastern treaty we should expect to find a historical introduction, a call to make a covenant, a statement of the stipulations, a summons to the witnesses, an oath, and a religious ceremony in which the covenant was ratified. All of these may be obtained here, but only by combining both the $\mathrm{J}$ and the $\mathrm{E}$ narratives. It is logically possible that both $\mathrm{J}$ and $\mathrm{E}$ drew on a Grundlage, ${ }^{11}$ extracting different elements from it to suit their own purpose. But it is just as easy to argue that here we have in a free narrative which defines an actual event, all the essential elements of a typical Near Eastern tribal agreement set out in the typical reiterative style of the story teller rather than in the formal fashion of the treaty document. What is important, however, is that in order to obtain the total covenant Gattung, the material of both $\mathrm{J}$ and $\mathrm{E}$ is required. This suggests a certain artificiality in the attempt to analyse such a piece of narrative as this into various strata. There is, in any case, no agreement about the exact analysis. ${ }^{12}$

The method used in this discussion may be applied in numerous other passages in the Old Testament.

(b) The possible authenticity of certain details in some pre-exilic sections of the Old Testament.

Close study of the Hittite treaties of the second millennium B.C. has shown the presence of certain details which may also be found in the early literature of the Old Testament. Thus the value of a

I . M. Noth, Uberlieferungsgeschichte des Pentateuch, 1948, pp. 466 .

12. Note the complex analysis of C. A. Simpson, Genesis, IB, I, pp. $716 f$. 
change of person or number as a criterion for literary analysis may well be ruled out in view of the use of precisely this technique in ancient documents of the Near East, both treaties, and other pieces of literature. ${ }^{13}$ Again, the Hittite treaties include threats of exile or loss of land or families among their 'curses'. The presence of similar threats in Leviticus 26 and Deuteronomy 28 need not, therefore, be regarded as a sign of post-exilic editing. Nor need we resort to the Deuteronomic editor so frequently once the presence of the elements of the standard treaty pattern is allowed to suggest something original rather than something intrusive. Thus when M. Noth wishes to explain Joshua 24: $19-24$ as Deuteronomic in character ${ }^{14}$ it should be noted that these verses contain the declaration of the curses (verse 20) and perhaps, by inference from the phrase 'he hath done you good', the blessings. The calling of witnesses also appears here. Both of these elements were essential to the acceptance of a treaty among the Hittites and are hardly to be eliminated from a covenant ceremony in Joshua's day. Again, there are elements in Exodus 24: I I-28 which fit the covenant or treaty context extremely well although the passage has created problems for the commentators. 15 Even if a certain amount of editorial work be allowed there is much in the passage which would suggest a historical occasion of covenant renewal. Again, the careful listing of vineyards, oliveyards, etc., in Joshua 24: I3 is quite in the fashion of ancient treaty documents and need not be regarded as Deuteronomic. ${ }^{16}$

The presence of such details as these in many other passages in the Old Testament need not, therefore, point to editorial insertions, even if, at times, there was a re-writing of ancient materials.

\section{(c) Implications for the literary and pre-literary history of the Pentateuch.}

The tendency of G. von Rad, M. Noth and others to separate the Exodus and Sinai traditions is difficult to maintain if the Sinai event be understood as a typical covenant ceremony of the second millennium B.C. Its very literary form demands a historical introduction against which the appeal to Israel might be made to enter into a covenant with Yahweh as her suzerain and Lord. Both the earliest

I3. E.g. Josh. 24: 6ff., uses 'he', 'the Lord' and 'I', all with reference to Yahweh.

I4. M. Noth, Fosua, p. I 36 .

15. See M. Noth, Exodus, ET. 1962, pp. 261-267.

I6. Gf. M. Noth, Fosua, pp. I35f., and note K. Baltzer, Das Bundesformular, I96o, and W. L. Moran, Biblica, 43, 1962, p. 103. 
treaties of the ancient Near East, say, prior to 1500 B.C. ${ }^{17}$ and the treaties of the first millennium B.C. appear to lack this historical introduction which is so common in the Hittite treaties of ca. I4001250 B.C. What other historical introduction or foundation for Yahweh's covenant with Israel can be suggested? The present Exodus story is an adequate background to the covenant appeal of Exodus 19: 5; Deuteronomy 4:1, 29:9, etc. If this is so, then in the pre-literary period of the Pentateuch the Exodus and Sinai events were already part of a historical continuity. Indeed the sequence, Exodus-Sinai-Wandering-Conquest was a historical sequence. It was for this reason that the literary form of the tradition took the shape it did, and not because an ideal pattern, borrowed from the Near Eastern treaty pattern, was read back into a number of isolated events which were given an 'all Israel' orientation and cast into the shape in which they now exist.

(d) The Vocabulary of Covenant in the Old Testament.

A comparison of the vocabulary used in the Near Eastern treaties and in the Old Testament passages which are concerned with the covenant between Yahweh and Israel will reveal that the formal and legal elements of the Old Testament vocabulary are closely parallel to those used in the Near Eastern treaties. A certain number of terms are etymologically equivalent, and others are semantically equivalent. The terms for 'covenant', 'covenant stipulations', 'witness', 'oath', 'blessing', 'curse', 'treaty document', 'obedience', etc., are closely equivalent. On the other hand, the formal and legal elements of the covenant did not exhaust the covenant idea which had to beenlarged to include such concepts as 'love', 'election', 'covenant loyalty', 'forgiveness', 'repentance', and a number of ethical concepts which were to characterise the covenant people. The Old Testament understanding of covenant had depths of meaning which were never dreamed of in the secular covenants between the suzerains and vassals of the ancient Near East. A profound transformation and an intimately personal application of the covenant idea took place when Israel adapted the Near Eastern metaphor to express her covenant with Yahweh.

These illustrations of the way in which the form and language of the covenant Gattung may be used in Old Testament research by no means exhaust the possibilities which are presented to the Old Testament scholar. The relevant journals of the past decade, and more particularly of the past five years will show how significant the idea has become for Old Testament study.

I 7. H. Otten, $\mathcal{F} C S$, 5, I951, pp. I 29-1 32; W. L. Moran, loc. cit., p. I05. 